\title{
The effect of a
} selective cyclooxygenase-2 (COX-2) inhibitor on the proliferation rate of retinoblastoma cell lines

${ }^{1}$ The Henry C Witelson Ocular Pathology Laboratory, McGill University, Montreal, Canada

${ }^{2}$ Ophthalmology Department, Federal University of São Paulo, São Paulo, SP, Brazil

${ }^{3}$ Retina and Oncology Services, Department of Ophthalmology, Santa Casa of Porto Alegre, Porto Alegre-RS, Brazil

Correspondence: JP de Souza Filho, Lyman Duff Building, 3775 University Street, Room 216, Montreal-QC H3A 2B4, Canada

Tel: + 15143987192 ext. 00384;

Fax: + 15143985728

E-mail: jpessoafilho@

hotmail.com

Received: 2 February 2005 Accepted in revised form: 12 April 2005

Published online:

17 June 2005

Financial interest: None
Abstract

Purpose To examine the effect of nepafenac, a selective cyclooxygenase-2 (COX-2) inhibitor, on the proliferation rate of two human retinoblastoma $(\mathbf{R b})$ cell lines.

Methods Two human $\mathbf{R b}$ cell lines (WERI-RB and Y79) were cultured. COX-2 expression in these cell lines was verified by imunocytochemical analysis of cytospin sections and Western blotting. An MTT-based proliferation assay was used to compare $\mathbf{R b}$ cell growth with and without amfenac, the active metabolite of nepafenac. The averaged results per condition were recorded. The Student's $t$-test was used to compare results from the cells cultured with and without amfenac.

Result The Y79 cell line showed a higher proliferative rate than the WERI-RB cell line. Both cell lines were negative for COX-2 expression by immunocytochemical analysis; however, both cell lines were positive for COX-2 expression by Western blot. When amfenac was added to both of the cell lines, a statistically significant reduction in proliferation was observed in both cell lines. The two $\mathrm{Rb}$ cell lines were positive for COX-2 only in the Western blot, indicating that they probably express low levels of COX-2, which was undetectable by immucytochemical analysis.

Conclusion The selective, anti-COX-2 molecule amfenac inhibited proliferation of both tested $\mathbf{R b}$ cell lines. Further trials should be undertaken to study the effect of selective COX-2 inhibitors on $\mathrm{Rb}$.
JP de Souza Filho',2, ZMS Correa ${ }^{1,3}$, JC Marshall', E Anteka', AB Coutinho', ${ }^{1,2}$ MC Martins ${ }^{2}$ and MN Burnier J $r^{1}$
Eye (2006) 20, 598-601. doi:10.1038/sj.eye.6701938; published online 17 June 2005

Keywords: COX-2; retinoblastoma; nepafenac; cell lines; immunocytochemistry

\section{Introduction}

Retinoblastoma $(\mathrm{Rb})$ is the most common malignant intraocular tumour in children and overall, the most common retinal tumour. ${ }^{1} \mathrm{Rb}$ is a unique human disease characterized by a concentric arrangement of proliferating viable cells forming sleeves around blood vessels. At the periphery of the sleeves, the cells become necrotic. The growth rate of $\mathrm{Rb}$ apears to be more dependent on the ability of the tumour to induce neovascularization than on the inherent growth rate of the neoplastic cells. ${ }^{2}$

There is published evidence that cyclooxygenase-2 (COX-2)-derived prostaglandins contribute to tumour growth by inducing newly formed blood vessels (neoangiogenesis) that sustain tumour cell viability and growth. ${ }^{3}$ Previous publications have demonstrated COX-2 expression in $\mathrm{Rb}$ specimens and have suggested a possible relationship between the expression of COX-2 and the genesis of this tumour. ${ }^{4-6}$

COX-2 is a prostaglandin synthetase involved in inflammatory processes, growth, and progression of a variety of human cancers as well as possible immune responses. ${ }^{4,7}$ COX-2 contributes to tumorigenesis and the malignant phenotype of tumour cells through several mechanisms such as the increase in production 
of prostaglandins, the conversion of procarcinogens to carcinogens, the inhibition of apoptosis, the promotion of angiogenesis, the increase in the invasiveness of cancer cells, and the modulation of inflammation and immunoresponse. ${ }^{8,9}$ Studies have shown in colorectal cancer that overexpresses COX-2, there is a $40-50 \%$ decrease in mortality among patients taking COX-2 inhibitors. $^{10,11}$

The purpose of this study is to examine the effect of nepafenac, a selective COX-2 inhibitor, on the in vitro proliferation rate of two human $\mathrm{Rb}$ cell lines.

\section{Materials and methods}

\section{Cell culture}

Two human $\mathrm{Rb}$ cell lines were used for this study (WERI-RB and Y79, American Type Culture Collection, Manassas, VA, USA). These cell lines were cultured in RPMI-1640 medium (500 ml) (Invitrogen Life Technologies, Burlington, Ontario, Canada), supplemented with $10 \%$ by volume heat-inactivated fetal bovine serum (FBS; Invitrogen), $1250 \mu \mathrm{g}$ of fungizone (Invitrogen), and $50000 \mathrm{U}$ of penicillin-streptomycin (Invitrogen). Cell pellets were resuspended to a dilution of $5 \times 10^{3}$ cells $/ \mathrm{ml}$ and cytospin slides were made. The slides were stored at $-20^{\circ} \mathrm{C}$ until used.

\section{Immunocytochemistry}

The cytospin slides were removed from $-20^{\circ} \mathrm{C}$ and left at room temperature overnight before being fixed with $2 \%$ paraformaldehyde for $30 \mathrm{~min}$. The paraformaldehydefixed samples were then tested for COX-2 expression by immunocytochemical analysis using a monoclonal mouse anti-COX-2 antibody (Zimed Laboratories, San Francisco, CA, USA; clone COX 229) at a dilution of $1: 50$.

\section{Western blot analysis}

Protein samples from two cell lines were prepared using $100 \mu \mathrm{l} / 10^{6}$ cells of $2 \times$ electrophoresis sample buffer (250 mM TRIS pH 6.8, 4\% SDS, 10\% glycerol, $0.006 \%$ bromophenol blue, $2 \% \beta$ mercaptoethanol), which was then boiled for $5 \mathrm{~min}$. Proteins were separated on $12 \%$ SDS-Page gel and transferred to a polyvinylidene difluoride (PVDF) membrane overnight. (Amersham Bioscience, Piscataway, NJ, USA).

The membrane was blotted for a specific antibody according to Proto Blot for Western blot alkaline phosphatase system (Promega Corporation, Nepean, Ontario, Canada). The primary antibody monoclonal mouse anti-human COX-2 (clone 229-Zymed, Laboratories, San Francisco, CA, USA) was used at the concentration of $3 \mu \mathrm{g} / \mathrm{ml}$. The secondary antibody ( $1: 8000)$ goat anti-mouse alkaline phosphatase-conjugated (Sigma-Aldrich, Oakville, Ontario, Canada) was used to visualize the proteins on the membrane. Cell lysate from macrophages stimulated with interferon gamma and LPS (Transduction Laboratories, BD Biosciences, San Diego, CA, USA) was used as a positive control.

\section{Proliferation assay}

An in vitro toxicology assay kit, MTT based, was used to evaluate the quantitative response by a cell population to external factors, whether due to an increase in cell growth, no effect or to a decrease in growth due to necrosis or apoptosis. This assay was used to compare $\mathrm{Rb}$ cell growth with and without amfenac, the active metabolite of the anti-COX-2 medication nepafenac (Alcon Laboratories Inc, Fort Worth, TX, USA). Briefly, all cell lines were seeded at a concentration of 5000 cells per well into a 96-well plate (Beckton Dickenson Labware, Bedford, MA, USA). Amfenac was added to the experimental wells of each cell line at the recommended $50 \%$ inhibitory concentration $\left(\mathrm{IC}_{50}\right.$ ) of $150 \mathrm{nM}$, while RPMI was added to the control wells. Cells were allowed to incubate for $48 \mathrm{~h}$ at $37^{\circ} \mathrm{C}$, in a humidified $5 \% \mathrm{CO}_{2}$ enriched atmosphere. The mitochondrial activity was assayed using the MTT assay done in six wells per condition. The entire assay was repeated three times. The average results per cell line were recorded for each condition. The Student's $t$-test was used to compare the in vitro proliferation rates of $\mathrm{Rb}$ cell lines cultured with and without amfenac.

\section{Results}

The two cell lines were negative for COX-2 expression by immunocytochemical assay. Both cell lines were shown to be positive for COX-2 expression when using Western blot (Figure 1).

The Y79 cell line showed a higher proliferative rate than the WERI-RB cell line with an average absorption of $0.91 \pm 0.09$ compared to $0.57 \pm 0.08$ (Figure 2). When amfenac was added to both of the cell lines, a statistically significant reduction in proliferation was observed in both of them $(P \leq 0.005)$. The Y-79 cell line revealed however a more significant decrease in proliferation when amfenac was added $(P<0.001)$. The Y79 cell line also had a decrease in absorption to $0.7 \pm 0.07$, while the WERI-RB cell line showed a decrease to $0.47 \pm 0.03$.

\section{Discussion}

The presence of COX-2 in the retina as well as the antiangiogenic effects of selective COX-2 inhibition in 


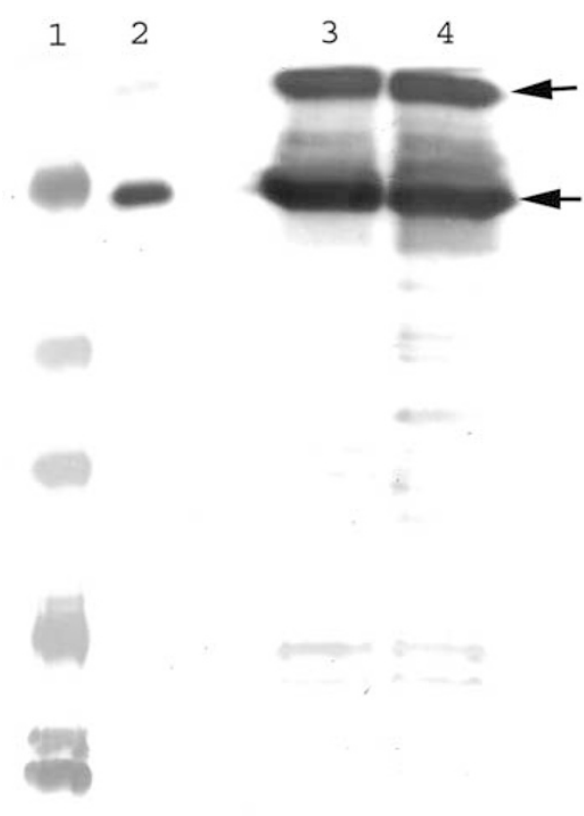

Figure 1 Western blot of COX-2 expression in two Rb cell lines. Lane 1 is the marker, lane 2 is the positive control, lane 3 is the WERY RB cell line, and lane 4 is the Y79 cell line. Arrows indicate bands that have stained positive for COX-2 protein in the two RB cell lines.

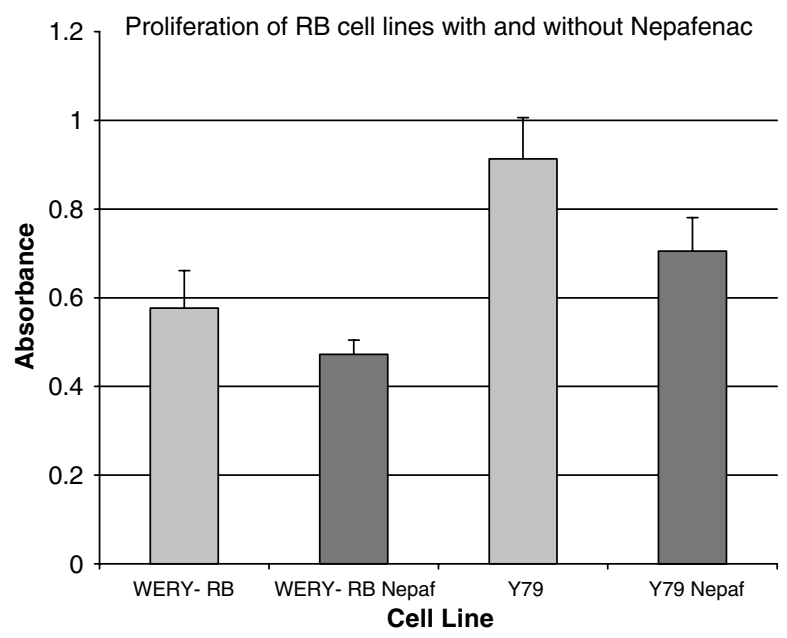

Figure 2 Proliferation rate of two retinoblastoma cell lines (WERI-RB and Y79) with and without amfenac, the active metabolite of nepafenac, an anti-COX-2 medication.

both developmental and pathologic retinal angiogenesis has been demonstrated..$^{12}$ Anti-COX-2 agents have shown promising antitumour efficacy in lung cancer and a large variety of solid tumours that rely on COX-2related mechanisms for growth and survival. ${ }^{13} \mathrm{COX}-2$ protein overexpression has been reported to correlate with decreased survival in patients with cervical cancer after treatment with radiotherapy ${ }^{14}$ and, as previously mentioned, a possible relationship between the expression of COX-2 and the genesis of $\mathrm{Rb}$ has been suggested. ${ }^{4-6}$

According to Chevez-Barrios et al (2000), the same $\mathrm{Rb}$ cell lines used in this study (WERI-RB and Y79) have very distinctive behaviour as observed in a murine animal model. When inoculated in these animals, the Y-79 cell line generated aggressive tumours with invasive and metastatic potential. On the other hand, the WERI$\mathrm{RB}$ cell line gave rise to localized tumours that only invaded the anterior structures of the eye without extraocular spread or metastasis..$^{15}$ In the study herein, the proliferation rate observed in these two cell lines supported that publication, confirming a more aggressive potential of the Y-79 cell line.

COX-2 expression in $\mathrm{Rb}$ specimens has been reported in both well and poorly differentiated tumours.

However, a more diffuse and pronounced reaction was observed in the undifferentiated tumours. ${ }^{4}$ Considering the reported findings, it is understandable that amfenac presented a more accentuated inhibitory effect when added to the more aggressive cell line with the higher proliferation rate, which translates into a more undifferentiated cell type.

The relevance of COX-2 overexpression in $\mathrm{Rb}$ has not been determined and neither has a potential clinical use in patients. There are only two publications investigating $\mathrm{COX}-2$ expression in $\mathrm{Rb}$ and neither of them discusses the possibility of a clinical application such as using an anti-COX-2 medication to control tumour proliferation ${ }^{4,6}$ possibly in conjunction with chemotherapeutics.

According to the findings herein, the use of an anti-COX-2 compound considerably inhibited the proliferation of both $\mathrm{Rb}$ cell lines. Extrapolating this finding to the clinical practice can make an important point. If this prostaglandin has the same behaviour in $\mathrm{Rb}$ as in other tumours, ${ }^{7-9}$ it is possible to speculate a future clinical use of amfenac in patients with $\mathrm{Rb}$, regardless of the impossibility of biopsying these tumours for COX-2 immunoassay due to potential spreading.

Many studies have shown that anti-COX-2 medications induce apoptosis in various cancer cells by different mechanisms depending on the cell type. ${ }^{16}$ The precise cellular target(s) of these COX-independent effects have not been elucidated. ${ }^{17}$ The in vitro antiproliferative effect of anti-COX-2 drugs on cancer cell lines has been determined. This effect was found to be similar regardless of the expression of COX-2 in epithelial cell lines. This effect also extends to COX-2negative breast, cervix, prostate, and ovarian carcinoma cell lines. ${ }^{16,17}$ While the two $\mathrm{Rb}$ cell lines used in this experiment were found to express COX-2 by Western blot, they were negative when assayed by 
immunocytochemistry. This probably indicates that both cell lines expressed low levels of COX-2, which were not detectable using immunocytochemical methods.

Therefore, the use of selective COX-2 inhibitors, such as amfenac, may be useful even in cases where tumours were not seen to express COX-2 in

immunocytochemistry.

Recently, there has been much discussion over the safety of systemic COX-2 inhibitors, most notably celecoxib. ${ }^{18}$ In our study we used amfenac, the active metabolite of nepafenac, which has been formulated to be administered as eye drops and therefore likely presents a more local treatment to the eye than oral medications. ${ }^{19}$

In conclusion, the selective anti-COX-2 molecule amfenac inhibited the proliferation of both tested $\mathrm{Rb}$ cell lines despite the fact that both cell lines were negative for COX-2 expression. This may indicate that a secondary pathway is involved in the effect of amfenac upon cellular proliferation. Further trials should be undertaken to study the effect of selective COX-2 inhibitors on $\mathrm{Rb}$.

\section{Acknowledgements}

JP de Souza Filho is supported by CAPES (Brazil) and The Sean Murphy Fellowship in Ocular Pathology (PAAO and McGill University).

\section{References}

1 Deegan WF. Emerging strategies for the treatment of retinoblastoma. Curr Opin Ophthalmol 2003; 14(5): 291-295.

2 Burnier MN, McLean IW, Zimmerman LE, Rosenberg SH. Retinoblastoma. The relationship of proliferating cells to blood vessels. Invest Ophthalmol Vis Sci 1990; 31(10): 2037-2040

3 Masferrer JL, Leahy KM, Koki AT, Zweifel BS, Settle SL, Woerner BM et al. Antiangiogenic and antitumor activities of cyclooxygenase-2 inhibitors. Cancer Res 2000; 60(5): 1306-1311.

4 Karim MM, Hayashi Y, Inoue M, Imai Y, Ito H, Yamamoto M. Cox-2 expression in retinoblastoma. Am J Ophthalmol 2000; 129(3): 398-401.

5 Mendez MC, Fernandes L, Caissie AL, Callejo SA, Burnier MN. Cyclooxygenase-2 (COX-2) expression in retinoblastoma. Invest Ophthalmol Vis Sci 2002; 43, ARVO B579.
6 Mendez MC, Fernandes L, Caissie AL, Callejo SA, Burnier Jr MN. Cyclooxygenase-2 (COX-2) Expression In Retinoblastoma. Invest Ophthalmol Vis Sci 2002; 43(Suppl): E-Abstract 2582.

7 Shono T, Tofilon PJ, Bruner JM, Owolabi O, Lang FF. Cyclooxygenase-2 expression in human gliomas: prognostic significance and molecular correlations. Cancer Res 2001; 61(11): 4375-4381.

8 Kawamori T, Rao CV, Seibert K, Reddy BS. Chemopreventive activity of celecoxib, a specific cyclooxygenase- 2 inhibitor, against colon carcinogenesis. Cancer Res 1998; 58(3): 409-412.

9 Dempke W, Rie C, Grothey A, Schmoll HJ. Cyclooxygenase2: a novel target for cancer chemotherapy? J Cancer Res Clin Oncol 2001; 127(7): 411-417.

10 Smalley WE, DuBois RN. Colorectal cancer and nonsteroidal anti-inflammatory drugs. Adv Pharmacol 1997; 39: 1-20.

11 Kawamori T, Wakabayashi K. COX-2 and prostanoid receptors: good targets for chemoprevention. J Environ Pathol Toxicol Oncol 2002; 21(2): 149-153.

12 Wilkinson-Berka JL, Alousis NS, Kelly DJ, Gilbert RE. COX-2 inhibition and retinal angiogenesis in a mouse model of retinopathy of prematurity. Invest Ophthalmol Vis Sci 2003; 44(3): 974-979.

13 Abou-Issa H, Alshafie G. Celecoxib: a novel treatment for lung cancer. Expert Rev Anticancer Ther 2004; 4(5): 725-734.

14 Nix P, Lind M, Greenman J, Stafford N, Cawkwell L. Expression of Cox-2 protein in radioresistant laryngeal cancer. Ann Oncol 2004; 15(5): 797-801.

15 Chevez-Barrios P, Hurwitz MY, Louie K, Marcus KT, Holcombe VN, Schafer P et al. Metastatic and nonmetastatic models of retinoblastoma. Am J Pathol 2000; 157(4): 1405-1412.

16 Kim SH, Song SH, Kim SG, Chun KS, Lim SY, Na HK et al. Celecoxib induces apoptosis in cervical cancer cells independent of cyclooxygenase using NF-kappaB as a possible target. J Cancer Res Clin Oncol 2004; 130(9): 551-560.

17 Waskewich C, Blumenthal RD, Li H, Stein R, Goldenberg $\mathrm{DM}$, Burton J. Celecoxib exhibits the greatest potency amongst cyclooxygenase (COX) inhibitors for growth inhibition of COX-2-negative hematopoietic and epithelial cell lines. Cancer Res 2002; 62(7): 2029-2033.

18 Graham DJ, Campen D, Hui R, Spence M, Cheetham C, Levy $\mathrm{G}$ et al. Risk of acute myocardial infarction and sudden cardiac death in patients treated with cyclo-oxygenase 2 selective and non-selective non-steroidal anti-inflammatory drugs: nested case-control study. Lancet 2005; 365(9458): 475-481.

19 Takahashi K, Saishin Y, Mori K, Ando A, Yamamoto S, Oshima $Y$ et al. Topical nepafenac inhibits ocular neovascularization. Invest Ophthalmol Vis Sci 2003; 44(1): 409-415. 